\title{
Comparative Cooperative Learning Type NHT (Numbered Head Together) and TAI (Team Assisted Individualization) Volleyball Classes at Junior High School in Makassar, Indonesia
}

\author{
Hasmyati, Suwardi \\ Faculty of Sports Science, Universitas Negeri Makassar, Indonesia
}

\begin{abstract}
Physical Education as one of the branches of science are considered to contribute positively in spurring science and health. Teaching strategies are deemed relevant if able to deliver students to achieve educational goals through learning. Some types of cooperative learning models are NHT (Numbered Head Together) and TAI (Team Assisted Individualization). Type of collaborative learning is considered able to facilitate students whose ability is different. With this learning mechanism, students can learn from their peers and are expected to improve education achievement both individual and classical performance. However, the comparison or comparison of existing types has not been visible, so that valid comparable data required in applying a suitable learning to students. Based on this, it needs research that is Comparative Cooperative Learning Type NHT (Numbered Head Together) and TAI (Team Assisted Individualization) volleyball class First School. The results of this study show that the average comparison between NHT type cooperative learning and TAI type cooperative learning shows a mean difference of 13.87 indicating that collaborative learning of NHT model is more efficient than cooperative learning type TAI.
\end{abstract}

Keywords: Comparative, NHT (Numbered Head Together), TAI (Team Assisted Individualization).

\section{Introduction}

Education is an important factor for the survival of the nation and supporting factors that play a significant role in all sectors of life because the quality of a country is very close to education [1]. Education is a service in the form of culture process, where this understanding implies the existence of input and output. In this case, the inputs are learners, facilities, infrastructure, and environment, while the output is education services, graduates or alumni and research results.

One of the internal factors that support the learners' efforts leads them to changes in situations as well as changes in progress in the intellect development process in particular and the process of mental development, as well as personal attitudes. Learning outcomes achieved by the students influenced by two main factors namely the factor of within the students themselves and factors that come from outside the student self [2]. Factors in others that support the success of student learning are the activity of students in the classroom. Failure and success rely heavily on students because individuals have different traits and characteristics. The more active students in the learning process, both independent and in school the better achievement of learning [3].

Physical Education as one of the branches of science is considered to contribute positively in spurring science and health. The opinion that physical education is an integral part of the overall educational process [4]. The fields and targets pursued are the physical, mental, emotional and social development of healthy citizens through the medium of physical activity in an efficient, improve the quality of work (performance), learning ability and health. So physical education becomes very important in efforts to improve the quality of teaching.
A student is said to have learned if there has been a change of behaviour in him. The desired changes as a result of learning include the cognitive, affective, and psychomotor aspects [5]. The cognitive aspect concerns the acquisition of new knowledge or the addition of existing knowledge. The active aspect concerning the development of new attitudes and interests or the perfection of beliefs and interests that have possessed, while the psychomotor aspects are related to the acquisition of new skills or the achievement of competencies possessed [6].

Quality education is education that produces graduates who have the ability that includes the above three aspects, namely cognitive aspects, affective aspects, psychomotor aspects, to follow even a pioneer of renewal in education. One of the restoration efforts in the field of teaching is the updating of strategies or improving the relevance of teaching methods [3].

Teaching strategies are considered relevant if able to deliver students to achieve educational goals through learning. An instructional strategy is a way that teachers use in teaching subject matter by focusing on learning situations to achieve goals [7]. A good teaching strategy is a plan that requires student activeness in thinking and acting confidently and creatively in developing the material that has mastered.

One method of learning Cooperative learning system is one method that should get attention and choice for teachers in providing a subject teaching. Learning by the cooperative method is a method of learning where students learn in small groups that have different levels of ability, this little group of each member is required to work together with members of one group with another [8]. Type of cooperative learning is 


\section{International Journal of Science and Research (IJSR) \\ ISSN (Online): 2319-7064}

Index Copernicus Value (2015): 78.96 | Impact Factor (2015): 6.391

considered able to facilitate students whose ability is different. Students who have more knowledge about the material studied can show concern and responsibility to their peers. The student can actualise the ability more to be concerned about his friends who are less able and nourish the sense of shared responsibility in learning, and foster selfconfidence [9]. With this learning mechanism, students can learn from their peers and are expected to improve education achievement both individual and classical performance. However, the comparison or comparison of existing types has not been visible, so that valid comparable data required in applying a suitable learning to students.

\section{Method}

This study is an experimental research that will compare the results of treatment of two types of cooperative learning that is TAI type and NHT type.

The number of samples used in this study was 32 students for each experimental class. The research design is Post Test Only Comparative Group Design [10].

$\begin{array}{cccccc} & \text { Class } & & \text { Treatment } & & \text { Post-test } \\ & \mathrm{K}_{1} & > & \mathrm{X}_{1} & > & \mathrm{O}_{1} \\ \mathrm{~K}_{2} & > & \mathrm{X}_{2}> & \mathrm{O}_{2}\end{array}$

Information:

$\mathrm{K}_{1}=$ NHT type experiment class 1

$\mathrm{K}_{2}=\mathrm{TAI}$ type experiment class 2

$\mathrm{X}_{1}=$ NHT type learning treatment

$\mathrm{X}_{2}=\mathrm{TAI}$ type learning treatment

$\mathrm{O}_{1}=$ Post-test for Experiment Class 1

$\mathrm{O}_{2}=$ Post-test for Experiment Class 2

Data collection techniques used in this study are observation and test sheets. The comment sheets are used to collect data on student learning activity indexes (psychomotor, cognitive and affective). Meanwhile, to obtain data of student learning result used the product of learning test.

Learning for both types is effective if at least $80 \%$ of students are in the high or very high category and $80 \%$ of observed aspects of activity are at least in the effective or highly effective group.

Data analysis techniques with inferential statistics used to test the research hypothesis. Check the hypothesis used parametric statistics with the $\mathrm{t}$ test. With the level of significance to test the hypothesis used $\alpha=0.05$. The type of t-test used is an independent sample T-test.

The decision-making criterion is accepted $\mathrm{H}_{0}$ if the significance level $\mathrm{p} \geq 0.05=\alpha$, but reject $\mathrm{H}_{0}$ if the significance level $\mathrm{p}$ has other prices. For inferential statistics used SPSS statistical analysis program. But before the hypothesis testing done before the prerequisite test of normality and homogeneity test.

\section{Result and Discussion}

\subsection{Description of Analysis}

Description of research results describe the characteristics of study respondents about the learning outcomes of the Volley Ball class, in the learning both in the experimental class 1 and in the experimental class 2. The descriptions are each described as follows:

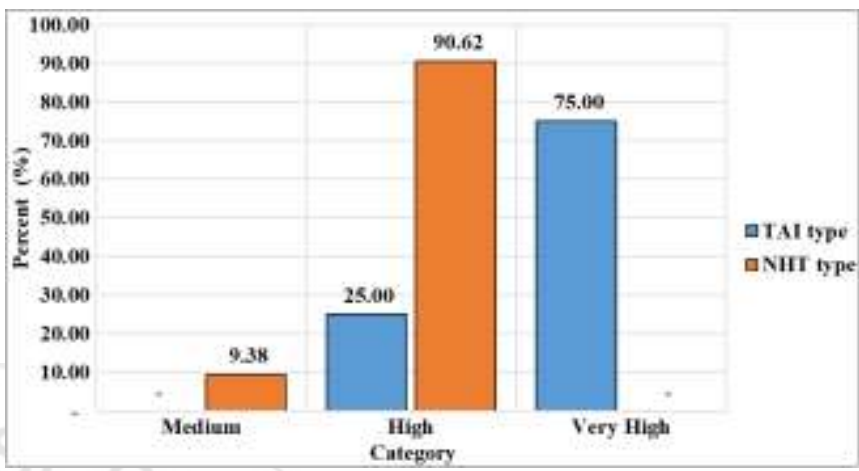

Figure 1: Comparison of education course learning experiments of TAI and NHT types.

Figure 1 shows for the learning NHT in the category of being obtained a percentage of $9.38 \%$ (3 students), for the high group got rate $90.62 \%$ (29 students). From these results, it saw that the achievement of dominant learning outcomes in the top category.

Then for the learning TAI with the group is obtained a percentage of $25.00 \%$ (8 students), for the high group got rate $5.62 \%$ (24 students). From these results, it saw that the achievement of dominant learning outcomes in the top category.

\subsection{Minimum Exhaustiveness Criteria}

Minimum Exhaustiveness Criteria is the lowest approach to state learners reach completeness. Minimum Exhaustiveness criteria must establish at the beginning of the school year by the educational unit based on the results of the subject teachers' deliberations in educational units or some instructional units that have similar characteristics [11]. Based on the minimum completeness criteria applicable in junior high school used to determine the level of achievement of student learning outcomes.

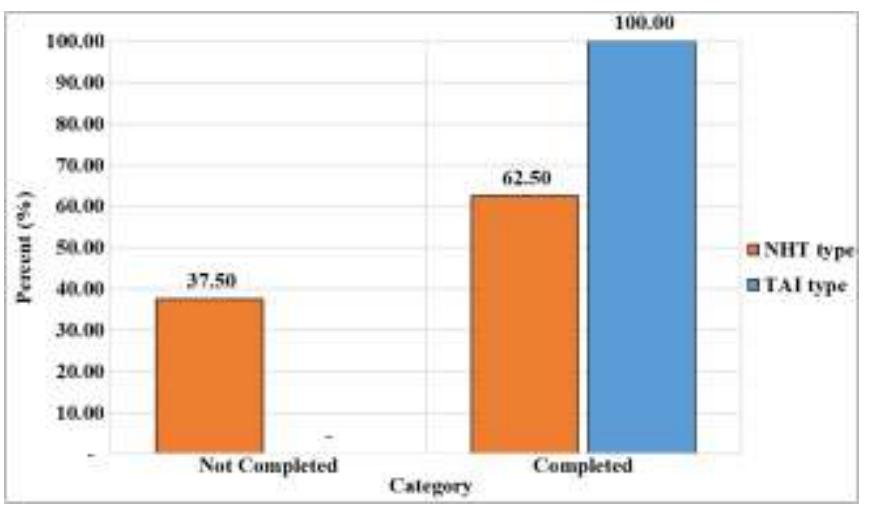

Figure 2: Comparison of mastery of student learning NHT and TAI

Volume 6 Issue 9, September 2017

www.ijsr.net

Licensed Under Creative Commons Attribution CC BY 


\section{International Journal of Science and Research (IJSR) \\ ISSN (Online): 2319-7064}

Index Copernicus Value (2015): 78.96 | Impact Factor (2015): 6.391

Figure 2 for NHT model learning has 12 students or $37.50 \%$ who have not reached the minimum mastery criteria, and 20 students or $62.50 \%$ who have attained the minimum proficiency standards. Students who have achieved the minimum proficiency standards of $62.50 \%$ far above the standard completion requirements that have been determined then the artistic completeness can meet so that cooperative learning type NHT can be said sufficient when viewed from the aspects of learning outcomes.

Then for TAI model knowledge, there are no students who have not reached the minimum completeness criteria, and 32 students or $100 \%$ who have achieved the minimum mastery criteria. Students who have attained the minimum proficiency standards of $100 \%$ far above the standard completion requirements that have been determined then the artistic completeness can meet so that cooperative learning type TAI can be said to be effective when viewed from the aspects of learning outcomes.

\subsection{Independent Sample T Test}

Before the analysis of Independent Sample T Test done than first check the distribution of research data by using the normality test and homogeneity test.

Check the normality of data that researchers use the normality test using SPSS application program. The normality test is used to determine whether the data used in the study is from a normally distributed population or not. Normally distributed data if the probability (p) value in the Kolmogorov-Smirnov test is greater than alpha $\alpha=0$. [12]. Normality test results can be seen in table 1 as follows:

Table 1: Kolmogorov-Smirnov Normality Test

\begin{tabular}{|c|c|c|c|}
\hline Class & Value-p & Alpha & Decision \\
\hline Experiment 1 & 0.094 & 0.05 & Normal \\
\hline Experiment 2 & 0.200 & 0.05 & Normal \\
\hline
\end{tabular}

From the result of normality test of learning result above is obtained on Kolmogorov-Smirnov test in experimental class 1 p-value $=0.094>\alpha$ hence can be decided that data in experiment class 1 comes from normally distributed data. Similarly, in the experimental class 2 p-value $=0.200 \geq \alpha$, it can determine that the data in experiment 2 class comes from normally distributed data.

Homogeneity test aims to determine whether the sample comes from a population that is homogeneous distributed or not. One way of making decisions is to use the Test of Homogeneity of Variance [13]. The test criterion performed if the p-value of Based on Mean in Bartlett's test is greater than alpha $=0.05$. The results of homogeneity test computing presented in table 2 below:

Table 2. Test of Homogeneity of Variance

\begin{tabular}{|c|c|c|c|c|}
\hline & Bartlett Statistics & df1 & df2 & Sig. \\
\hline Based on Mean & 1.199 & 1 & 60 & 0.273 \\
\hline
\end{tabular}

From table 2 we get the p-value of Based on Mean is $\mathrm{p}=$ 0.273 . Because the value of $p=0.273>\alpha=0.05$, then the data in this research comes from a population that varies homogeneous.

With the fulfilment of normality and homogeneity of data than hypothesis testing can do by using t-test Independent Sample T-test. The decision-making criterion is accepted $\mathrm{H}_{0}$ if the significance level $\mathrm{p} \geq 0.05=\alpha$, but reject $\mathrm{H}_{0}$ if it is otherwise.

Table 3: Independent Sample T Test Results

\begin{tabular}{|l|r|r|r|}
\hline & Value-p & Alpha & Decision \\
\hline NHT-TAI & 0.000 & 0.05 & $\mathrm{H}_{1}$ Accept \\
\hline
\end{tabular}

From the result of hypothesis test above using Independent Sample $\mathrm{T}$ Test on a comparison of learning effect using cooperative learning type NHT and TAI obtained p-value $0.000>\alpha$. Hence can be decided to accept alternative hypothesis stating that there is difference significantly between result learn by using NHT type cooperative learning with cooperative learning type TAI. Inferentially, there was an average difference of 13.87 between NHT type cooperative learning and TAI type cooperative learning. Shows that NHT type cooperative learning is more effective than TAI type cooperative learning.

Comparison of learning outcomes based on the achievement of the effectiveness of cooperative learning type TAI and NHT is determined based on the completeness of learning achievement classically. The result of the research shows that the two kinds of learning in the application have reached the completeness of classical learning outcomes in which both types achieve the artistic integrity of $62.50 \%$ for NHT type cooperative learning and $100 \%$ completeness for cooperative learning type TAI. This result is far above the specified criteria. Descriptively there are differences in learning outcomes that show NHT type cooperative learning is more effective than TAI type cooperative learning.

When viewed from the aspect of student learning motivation on cooperative learning type NHT, the results showed that there are $81.25 \%$ of students have the motivation to get to be at least high or very high while in cooperative learning type TAI, the results showed that there $90.63 \%$ of students have learning motivation is in the category of at least high or very high. The results showed, descriptively the students who are taught by cooperative learning type TAI have tertiary education motivation from students who are taught by cooperative learning type NHT.

Numbered heads together (NHT) is the most efficient and potential learning method to be used in the learning process; this is because learners are encouraged to collaborate with content related to the discussion material. The heterogenic response in the discussion adds to the students' understanding so that NHT methods are more efficient for use [14]. Supported by research conducted by [15] which shows learning outcomes with NHT methods increased from learners to $5 \%$ compared with traditional methods.

The NHT method also proved to be more effective than traditional learning methods with the subjects of the study of persons with disabilities that showed higher quiz values than

\section{Volume 6 Issue 9, September 2017}

www.ijsr.net

Licensed Under Creative Commons Attribution CC BY 


\section{International Journal of Science and Research (IJSR) \\ ISSN (Online): 2319-7064}

Index Copernicus Value (2015): 78.96 | Impact Factor (2015): 6.391

usual [16]. On the other hand, these learners also preferred the NHT method compared to traditional methods. NHT method is also actually used in the learning process for students who experience emotional and behavioural disorders. Supported by research [17] in which a student encounters behavioural and emotional problems in the learning process, in particular on the subject of mathematics, then the researchers apply the NHT method to the students. The results indicate that the student's learning achievement increased by up to $80 \%$ also showed enthusiasm and enjoyed the discussion of correct answers within the group.

The reinforced by research conducted by [18] comparing three learning designs: "response cards" ("RC"), "numbered heads together" (NHT). And "whole group question and answer" (WGQA) in grade VI students showed that NHT \& $\mathrm{RC}$ methods are far superior in improving student learning outcomes than from WGQA methods to students. Similarly, students who taught with cooperative learning type TAI, the results showed, overall students or $100 \%$ of students have high learning activity index, and all aspects of observed activities at least are in the effective or very effective category. Descriptively both types of knowledge have the same learning activity index. Based on the criteria of the effectiveness of education, it concluded that the two types of knowledge, i.e. cooperative learning type NHT and TAI model sufficient for applied in junior high school students

\section{Conclusion}

The average score of student learning outcomes taught by cooperative learning type of NHT is 73.39 and students who have reached the completeness of $62.50 \%$. So that the integrity of learning outcomes classically achieved and cooperative learning type TAI teaches the average score of student learning outcomes is 87.26 and students who have reached the mastery of $100 \%$ so that the completeness of learning outcomes also achieved classical. From the t-test analysis for the learning result data using independent samples test obtained the value of (p) $0.000>0.05$ means H1 accepted, or it can say that there are differences in student learning outcomes taught by cooperative learning type NHT with students taught by cooperative learning type TAI.

The average comparison between NHT type cooperative learning and TAI type cooperative learning shows a mean difference of 13.87 indicating that collaborative learning of NHT model is more efficient than TAI type cooperative learning.

\section{Acknowledgments}

The authors would like to thank Universitas Negeri Makassar and the Ministry of Research, Technology and Higher Education of the Republic of Indonesia who has provided financial support to this research.

\section{References}

[1] B.-Å. Lundvall, "National systems of innovation:
Toward a theory of innovation and interactive learning," vol. 2. Anthem Press, 2010.

[2] S. G. Paris and R. S. Newman, "Development aspects of self-regulated learning," Educ. Psychol., vol. 25, no. 1, pp. 87-102, 1990.

[3] J. E. Brophy, Motivating students to learn. Routledge, 2013.

[4] D. A. Wuest and C. A. Bucher, Foundations of Physical Education and Sport. St. Louis, Missouri: Mosby-Year Book, 1995.

[5] M. Liakopoulou, "The Professional Competence of Teachers: Which qualities, attitudes, skills and knowledge contribute to a teacher's effectiveness," Int. J. Humanit. Soc. Sci., vol. 1, no. 21, pp. 66-78, 2011.

[6] G. Siemens, Knowing knowledge. Lulu. com, 2006.

[7] W. McKeachie and M. Svinicki, McKeachie's teaching tips: Strategies, research, and theory for college and university teachers. Cengage Learning, 2010.

[8] S. Kagan, "The structural approach to cooperative learning," Educ. Leadersh., vol. 47, no. 4, pp. 12-15, 1989.

[9] G. Ghaith, "Effects of the learning together model of cooperative learning on English as a foreign language reading achievement, academic self-esteem, and feelings of school alienation," Biling. Res. J., vol. 27, no. 3, pp. 451-474, 2003.

[10] J. R. Fraenkel and N. E. Wallen, How to Design and Evaluate Research in Education, 7th ed. New York: McGraw-Hill Higher Education, 2009.

[11] Nasional, Departemen Pendidikan., "Penetapan Kriteria Ketuntasan Minimal.” Jakarta: Departemen Pendidikan Nasional, 2008.

[12] M. Sarstedt, E. Mooi, and T. Process, A Concise Guide to Market Research: The Process, Data, and Methods Using IBM SPSS Statistics, 2nd ed. New York: Springer, 2014.

[13] S. Santoso, SPSS 22 from Essential to Expert Skills. Jakarta: PT. Elex Media Komputindo, 2014.

[14] W. C. Hunter, L. Maheady, A. D. Jasper, R. L. Williamson, R. C. Murley, and E. Stratton, "Numbered heads together as a tier 1 instructional strategy in multitiered systems of support," Educ. Treat. Child., vol. 38, no. 3, pp. 345-362, 2015.

[15] R. Lince, "Creative Thinking Ability to Increase Student Mathematical of Junior High School by Applying Models Numbered Heads Together.," J. Educ. Pract., vol. 7, no. 6, pp. 206-212, 2016.

[16] T. Haydon, L. Maheady, and W. Hunter, "Effects of numbered heads together on the daily quiz scores and on-task behavior of students with disabilities," J. Behav. Educ., vol. 19, no. 3, pp. 222-238, 2010.

[17] W. Hunter and T. Haydon, "Examining the effectiveness of numbered heads together for students with emotional and behavioral disorders," Beyond Behav., vol. 22, no. 3, pp. 40-45, 2013.

[18] L. Maheady, J. Michielli-Pendl, B. Mallette, and G. F. Harper, "A collaborative research project to improve the academic performance of a diverse sixth grade science class," Teach. Educ. Spec. Educ., vol. 25, no. 1, pp. 5570, 2002.

Volume 6 Issue 9, September 2017

www.ijsr.net

Licensed Under Creative Commons Attribution CC BY 